\title{
Are Suburban Youth Becoming More Traditional? A Comparative Study on Young People from Muslim Backgrounds Living on the Outskirts of Madrid and Paris
}

\author{
Cecilia Eseverri-Mayer ${ }^{1}$ (D)
}

Accepted: 27 January 2021 / Published online: 16 February 2021

(C) The Author(s), under exclusive licence to Springer Nature B.V. part of Springer Nature 2021

\begin{abstract}
This paper compares how Muslim youth identify with traditional values in two disadvantaged areas: a banlieue of Paris and a barrio of Madrid. Research has revealed divergent forms of identification with Islam and tradition. In Les Bosquets (Paris), where the predominating context is one of ethnic segregations, a lack of civic participation, isolation from the city center, and increasing inequalities and Islamophobia, youth are exhibiting an ambivalent return to traditional values and building a new proud, combative and collective Islam. In the case of Madrid, young people distinguish between human/religious and traditional values while ignoring the latter values when they interfere with individual interests. Islam here is individual and compatible with a collective feeling of neighborhood, one built within a context of ethnic diversity, a less intense feeling of Islamophobia, greater accessibility to the cosmopolitan urban center, and dense networks of civil society that encourage local participation.
\end{abstract}

Keywords Muslim youth · Islam · Tradition · Isolation · Ethnic diversity · Islamophobia

\section{Introduction}

During the 1980s, young Muslims in Europe were mainly studied in terms of class and urban and social crisis (Touraine 1991; Castel 1995; Wacquant 2002; Dubet 1987). The riots and early anti-racism movements took center stage for sociologists. Nevertheless, and especially after $9 / 11$, sociological research has focused on issues of national and ethno-religious belonging.

Cecilia Eseverri-Mayer

ceciesev@ucm.es

1 Department of Sociology: Methodology and Theory, University Complutense of Madrid, Avenida Complutense 3, 28040 Madrid, Spain 
Some authors warn of the growing influence of a conservative and fundamentalist political Islam among young people and announce the re-Islamization and retraditionalization of Muslim-majority neighborhoods (Kepel 2013, 2015; Lagrange 2010; Nair 2015; Khan 2016). Other authors condemn the essentialism of these visions (Cesari 1999; Roy 2009; Modood 2005; O’Toole et al. 2015; Ramadan 2004; Kundnani 2007; Mavelli 2012; Fassin 2006).

The main results of research youth in Europe conclude that European Islam is individual-personal, autonomous, and free (Ramadan 2003, 2004). In disadvantaged urban areas, it is also solid (strongly held convictions and values), elastic (connecting with the international umma and breaking with national identities), and resilient (capable of adapting to each context and protecting itself from Islamophobia) (Mythen 2012).

However, though some more vulnerable neighborhoods may be fertile ground for extremism, if the current complexity of the Western practice of Islam is not analyzed, we will miss an opportunity to learn about the more innovative movements that might influence the future (Cesari 2004; Parekh 2008; Joly 2016).

This research has identified that the literature falls short in determining if there is really a new weight to ethnic norms in some neighborhoods and the real relationship between young people, Islam, and the traditions that get passed down by adults in the local surroundings, in short, how young people identify with, negotiate, and transform traditional values and conceived Islam. The life paths of young people of Maghrebi and sub-Saharan origin (between 18 and 25 years old) are examined in two of the most vulnerable urban areas of Paris and Madrid, Les Bosquets (Paris), and San Cristóbal (Madrid).

These cultural beliefs (Bourdieu 1979) cannot be understood without considering structural inequality, Islamophobia, and the racialized disadvantages that disenfranchised Muslims have faced for decades (Frost 2008; Mavelli 2012; Kundnani 2007). To this end, an analysis is performed taking the concept of identification as a reference point. Identification is understood as the emotional and psychological bond with the values and ideas of a certain group, which provides meaning to their everyday practices through a complicity that gets defined by a common language (Castells 1997). Setting aside the ambiguity of the word identity - employed as a catch-all term in both the academic circles and in the media- using the term identification allows us to detect the empirical evidence. This term allows us to understand not only the outcome, as something closed and fixed, but also the journey or process, with all its contradictions and ambiguities (Brubaker 2001).

\section{Islam and the State in France and Spain}

On July 25, 1995, Khaled Kelkal, son of Algerian immigrants and raised in the Parisian banlieue, set off a homemade bomb inside a train carriage at the Saint Michel station in Paris. This event rocked France. He was the first jihadist to have grown up in France. After the attack, Khosrokhavar (1996) stated that a new religion-the Islam of the banlieues - had been born in France. He also calmed public opinion, however, by describing the compatibility of this new Islam and the principle of laïcité. 
During the 1990s, this new religious identification was the product of the disaffection between young people and the republican model of integration (Roy 2005; Fassin 2006; Keaton 2006; Joly 2005). The institutionalization of social and local movements (such as the Beur Movement ${ }^{1}$ ) by the Socialist party, who offered their leaders parliamentary representation and abandoned its bases by demanding recognition of their ethnic and religious diversity, sowed even greater discontent in the suburbs. The most committed youth left the secular associations and found a new place in Islamic associations.

In 2004, the frustration and sense of discrimination grew even further when the government approved the law prohibiting the use of any religious symbols in the public sphere. A new generation of Muslims tried to explain to mainstream society that "they are not looking to break with a French identity but wish to assume it differently" (Khosrokhavar 1997: 117). But the discrimination and relegation continued, coming to the fore in 2005 in the northern banlieue, when the most violent urban riots in 40 years broke out following the death of two young people. Structural disadvantages and Islamophobia affect the lives of young people in the form of serious personality conflicts, social isolation, falling behind in school, and long-term unemployment (Khosrokhavar 1996; Bouamama 1993).

After each wave of riots, the secular State launched plans for urban renovation, usually failing to remember to fight against ethnic and social isolation and territorial discrimination (Wieviorka 1999). In addition, and paradoxically, "since the 1990s Islamic structures have become government allies in the fight against exclusion, drug addiction and youth violence" (Wihtol de Wenden and Leveau 2001: 123). Some scholars see this new religious leadership as the beginning of the influence of a new conservative Islam in certain urban areas (Kepel 2013).

In Spain, it was not until the 2000s that the State started discussing the need for an "integration model." Islam was recognized early on as a "deeply rooted" (notorio arraigo) religion within Spanish society because the political elite were seeking to refashion Spain as a modern society that values its Muslim heritage (Astor 2014). Religious and ethnic diversity was not yet an issue of public concern. In the case of Madrid, there was neither a specific philosophy on citizenship nor a specific idea on "national" identity (as is indeed the case in France and in the Region of Catalonia) (Arango 2009; Gil Araujo 2010; Prada 2000).

In addition, social intervention takes place at the local level (in the Autonomous Communities) in contrast with the centralized French model. Research has demonstrated that this institutional system facilitates the inclusion of Muslim youth through civil society and the educational system (Portes et al. 2016; Eseverri-Mayer 2019). The most recent survey conducted by Alejandro Portes and Rosa Aparicio (ILSEG Project) which sought to test the validity of Segmented Assimilation Theory in the Spanish context-also shows positive trends. Young people experience a kind of selective acculturation, which involves balancing the preservation of the original culture and identifying with the values and norms of mainstream society (Portes et al. 2017).

\footnotetext{
${ }^{1}$ First anti-racist movement born in the banlieues after the first urban riots in 1981. See (Eseverri-Mayer 2015) for more information.
} 
The final phase of the ILSEG project warns of increasing Islamophobia (Portes et al. 2018). The history of the Islamic presence on the Iberian Peninsula and the religious war during XVI might facilitate the construction of an "otherness" (Corpas 2010; Zapata 2006). However, though certain case studies do identify new forms of discrimination (Adlbi 2010; Eseverri-Mayer 2015), these experiences do not discourage youths to the point of marginalization.

According to several authors (López García 2009; Ramirez and Mijares 2009), the evolution of Islam in Spain went from immigrant Islam (private and communitarian practice mainly performed by men from the first generation) to a solid and engaged Islam (Eseverri-Mayer and Khir Allah 2020), represented by the second generation, practicing religion in an individual and spiritual way, combining their faith with their commitment to associative work as "good Spanish citizens" (Téllez Delgado 2011; Veredas 2011).

In France, by contrast, authors talk about an evolution which went from being the private/silent Islam of the parents in the 1960s-1970s, to a social/republican Islam represented by the older brothers active in the Beur Movement in the 1980s and 90s, and then to a new identitarian Islam in the 2000s (Jouili 2015; Jouili and Amirmoazami 2006; Cesari 2013a; Beaman 2016; Mogahed 2007; Killian 2007). As in Spain, most authors describe faith as independent and disconnected from collective identity, traditions, and religious authority (Roy 2006). Young Muslims in Europe are experiencing a process of secularization while also "putting personal choices ahead of religious tradition" (2003: 138). This individual logic means that Islam does not have a direct impact on the social and public behavior of young European Muslims (Cesari 2013b).

Young people are influenced by their family's cultural and religious values but not to the point of affecting their personal choices and individual agency (López and Olmo 1995). As Tariq Ramadan explains, the rediscovery of religion by second, third, and fourth generations in Europe "is a positive activity of self-confidence" (2002: 165), allowing them to distinguish between traditions (customs) and the religion itself, for the purpose of moving closer to an Islam thought to be "purer" and "more authentic." As Beaman concludes, "their religion does not hinder them from feeling French nor places them outside French secularism" (2016: 64).

Nevertheless, non-essentialist research has also shown that in some urban areas, an identity-based isolationism (Wacquant 2008) can develop. A new weight to authority and the patriarchal tradition, expressed as domestic violence and constraints on freedom, can be observed (Keaton 2006: 158; Khosrokhavar 1997:119). For young men and women choosing to leave Islam, it is also difficult to escape the weight of the community eye (le regard) (2006: 173). Freedom of conscience or dissent from social norms in poor areas of Europe can result in isolation from family and friends, stigmatization from community members, and violent or psychological abuse (Eseverri-Mayer 2019; Crul and Vermeulen 2003; Portes 1988; Waters et al. 2010; Waldinger 1995).

Consequently, a gap remains in the understanding of identification with traditional values and the conception of Islam in some of the poorest urban areas in Europe. This research provides an approach to two of them and is an opportunity to resolve two apparently irreconcilable sociological explanations. One warns of the arrival of a new ideological Islam, and the other describes the rise in Europe of a secular, individual, 
and free Islam that always manages to put personal choices ahead of religious tradition. This paper seeks to contribute to the international debate and capture the nuances of the disadvantaged youth.

\section{Methodology}

The empirical results of this article are drawn from the [name of the Project] project. The methodology has combined sociological intervention (SI) and ethnographic work through a comparative historical perspective. The fieldwork was carried out in Les Bosquets (Paris) between October 2013 and April 2014 and in San Cristobal (Madrid), between April 2014 and September 2014. The SI method stems from Touraine's Theory of Social Action (Touraine 1965, 1978, framed in the Weberian tradition. In it, the sociologist does not just observe but also intervenes in the field to learn youth experience and their capacity of action and innovation. This method consists of bringing 15 young participants together on a regular basis (over 3 months) to discuss key issues-education, security, politics, entrepreneurship, art, racism, and Islamophobia—with key speakers: a successful businessman, an artist of Maghreb origin, a teacher, two police officers, a local policy maker, an imam, and a leader of an anti-Islamophobia movement. These "open" sessions were interspersed with "closed" sessions, during which the previous discussions were analyzed and the first qualitative categories of analysis extracted.

This experience was also enriched with biographical interviews (Bertaux 1980) with old neighbors, members of civil society, and adults -9 from the second generation of Algerian, Moroccan, Malian, and Senegal origin in Paris and 11 from the first generation of Moroccan and Senegalese immigrants in Madrid. In addition, a youth exchange project was organized in Madrid in $2015^{2}$ with the aim of comparing (in situ) forms of identification with Islam and local traditions. This experience made it possible to interview at least one parent and repeat individual interviews with young people.

The qualitative sample in the two neighborhoods was composed of 15 youths in Les Bosquets and 15 in San Cristóbal (see Table 1). Getting access to vulnerable youth from a Muslim background in vulnerable neighborhoods is not easy. Prior experience in these urban areas (Eseverri-Mayer 2015, 2019) made it possible to gain trust with the young people and secure the commitment of the group for 3 months and during the trip to Madrid. The sample does not allow these results to be generalized across to other vulnerable urban areas. However, the real value of this research (and of the SI method) is the insight gained and the possibility of performing a deeper analysis of particular cases: learning about their environment, their families, and their biographies".

\footnotetext{
${ }^{2}$ The meeting took place in Madrid (May 2015) and allowed for four more sessions of SI to be done (Erasmus Plus Program: Grant Agreement Number 2014-2-ES02-KA105-000987).
} 
Table 1 Characteristics of qualitative sample

\begin{tabular}{lllll}
\hline & \multicolumn{2}{l}{ San Cristóbal } & & \multicolumn{2}{l}{ Les Bosquets } \\
\cline { 2 - 5 } & Female & Male & Female & Male \\
\cline { 3 - 5 } Studying & 7 & 3 & 7 & 6 \\
Not studying & 2 & 3 & 1 & 1 \\
Working & 2 & 3 & 4 & 4 \\
Not working & 7 & 3 & 4 & 3 \\
Born in Europe & 4 & 2 & 7 & 5 \\
Arrived before age 5 & 5 & 4 & 1 & 2 \\
Maghrebi origin & 5 & 3 & 4 & 3 \\
Sub-Saharan origin & 4 & 2 & 3 & 1 \\
Multiracial & 0 & 1 & 1 & 6 \\
Religious practicing & 6 & 3 & 7 & 1 \\
Not religious practicing & 3 & 3 & 1 & 7 \\
Total & 9 & 6 & 8 & \\
\hline
\end{tabular}

\section{Isolation, Feelings of Abandonment, and the Rise of a New Collective and Conservative Islam in Les Bosquets (Paris)}

The relationship between youths of Muslim background and the traditional values of their family or community is built up in a complex way in Les Bosquets, depending on the feelings of isolation (from social and ethnic diversity and from wider society) as well as feelings of abandonment (on the part of intuitions and the political elite). These feelings have made adherence to tradition and the relationship with Islam complex and ambivalent. In this section, evidence gleaned from the fieldwork and categories of analysis are laid out. A description of the location is also developed in accordance with the analyzed data ${ }^{3}$.

\section{Collective Loneliness and Feeling of Not Belonging to La Republique}

Ethnic and social isolation contributes to a sense of "disappointment with France" among young people. Located in northeast Paris (District 93, Seine-Saint-Denis), the neighborhood of Les Bosquets is one of the top 20 most vulnerable areas in the Ile de France, with a household income of 19,560 Euros per year (compared to 28,800 in the region) and an overall unemployment rate of $24 \%$ and $34 \%$ for young people (compared to an average of $11.7 \%$ and $9 \%$ in Ile de France) (Observatoire National des Zones Urbaines 2014). In terms of segregation, the inhabitants of Les Bosquets live $32 \mathrm{~km}$ from the center of Paris (an hour and a half by public transport). Though it cannot be considered a ghetto (Preteceille 2011), Les Bosquets does have a very significant concentration of one specific type of population, those from former colonies who are the least likely to be able to change neighborhoods (Pan Ké Shon 2011: 26-

\footnotetext{
${ }^{3}$ Detailed description of both urban areas from the ethnographic work can be found in (Eseverri-Mayer 2015, 2019).
} 
478). Under these circumstances, the proportion of young people from a Muslim tradition (18- to 25-year-olds of North African, Sub-Saharan African, and Turkish origin) is, according to the latest calculations, the largest group in the district, making up $76 \%$ of the total youth population (Tribalat 2010).

The lack of interethnic relationships and economic disconnection make young people feel anchored in Les Bosquets, distant from the opportunities of urban networks (Donzelot 2011). The neighborhood and internal networks are of no help and in fact mire them deeper into poverty. This isolation also generates a sense of having been abandoned by the institutions. In a world conditioned by globalization, austerity, and the economic crisis, isolation generates feelings of powerlessness, invisibility, and voicelessness. The historical perspective shows that this abandonment has lasted over 40 years in the outskirts of Paris and has taken root in a series of discriminatory practices and status and ethno-religious inequality involving violence and exclusion.

I am done with La France... We call the remodeled buildings 'misery in disguise' because they are nicely painted on the outside, but they hide a lot of suffering inside. The State remodels them, but they don't realize that our main problem is our disconnection from the world (...) and fuck, 30 years of racism and police brutality is a long time! (Second generation of Malian origin, 35 years old, street dance teacher)

Moreover, this collective loneliness and the experience of "not belonging to the world" include another important factor. The isolation is not merely political but also personal, economic, and social. It is also about feeling disconnected from their fellow citizens and political leaders. In Les Bosquets, the civic and political participation of the 1980s and 1990s is gone, civic associations have lost their social activism and been institutionalized, and intercultural and inter-religious dialogue is non-existent (EseverriMayer 2019). New generations have slowly stopped feeling French and are disconnected from participation as citizens. The director of the local mosque admits that most of the 600 young people who pass through the mosque each year lack an identity as French citizens.

France has offered them nothing and of course, the families, the communities are closed $[. .$.$] There is a great need to educate these young people, so they can be$ French and Muslim at the same time. (Second generation of Maghreb origin, 43 years old, engineer)

This discontent was accentuated by the 2004 Law prohibiting religious symbols. The young people saw these laws as stoking Islamophobic and discriminatory political discourse and legitimizing microaggressions. Young people struggling against a hostile environment identify with values opposed to the dominant society's (Castells 1997), toward a questioning the principle of laïcité and instead, are drawn to the community and belonging to religious values and traditions that protect them from stigmatization, isolation and feelings of abandonment.

This law was written against female students of the Muslim religion! They teach us liberté, égalité, fraternité, and little by little you tell yourself, damn it! That's not the 
way it is! You notice the police watching over you because of what you look like, especially our brothers, you see what happens to your female neighbor... buah, the high school counselor who sends you off to study hairdressing [...] In the group of girls at the mosque I feel at peace, in good company. That's something no one can take away from me! I feel like I'm part of them... (Third generation of Maghreb origin, 23 years old woman, studying to be a secretary)

\section{The Rise of a New Collective, Combative, and Conservative Islam}

This research has found that the combination of personal and political isolation is connected to the rise of a new collective Islam and new strong feelings toward traditions. Inclusion in the neighborhood mosque provides young people a sense of belonging. When the fieldwork was carried out (in 2015), there were two types of Islamic associations. The first was the Islamo-leftist associations, which predominantly did social work and were active in the socialist and communist party. This kind of association was losing adherents to the second type, united under the same umbrella organization: the Union of Muslim Associations (UAM93). These new structures managed to create the first Muslim school (École Reussite) and built the biggest mosque in Paris. Its president defends lobbying to get political representatives in local institutions and fighting against Islamophobia. This big new mosque (still under construction but located nearby) hosts international and local solidarity activities, as well as environmental seminars and sporting events. In addition to attending sermons and daily prayers, the young people are made to feel part of something greater. They provide a sense of belonging, which can be difficult to find in other secular and institutional spaces.

The success of these Islamic organizations is not due only to their emphasis on local participation and sense of belonging. It lies in their power to include anyone who might have felt ignored and abandoned by those in political and economic power. One major success for the Islamic movement in District 93 has been to define cultural and political identification in terms of religion and traditional values. The Islamic associations replace "republican and civic sentiment" with a participatory and conservative Islam that demands to be heard.

According to most from the Beur generation (second generation of North-African origin), the general mindset in the neighborhood has become closed, imposing on families a new rigorous moral code based on traditional patriarchal values. Political ideology has disappeared, and the sense of belonging associated with the political militancy has vanished. This situation leads to a new legitimacy of religious groups and its traditional values, while also making social control in the public space more effective.

We used to have a political identity, but now politics is dead. Young people just want to make money and consume [...] they've regained their dignity because they don't tolerate racism. But ultimately, the use of religion as a rallying call, in contrast to my generation, restricts their liberty. (42, second generation of 
Maghrebi origin, married to a white French, working in a Social Centre. Exmilitant of the Communist Party)

The return to a new morality can be appreciated in the growing incompatibility that the youth feel between certain values defended by the Republic and the traditional and patriarchal model defended by religious leaders. The imam from District 93 who was invited to the SI in Paris supported adapting Islam to life in France but considered patriarchy to be the only viable system. The youths, in contrast, failed to see the need for ijtihad (the work of interpreting the Koran and consequently the patriarchal model) and identified with dogma (the distinction between halal and haram) instead of with spirituality in their daily life. They also stood in opposition to the central role of science in education and the new tolerance toward civil and individual rights. These quotations demonstrate this new conservativism.

If I fancy a French guy, I look the other way, I control myself. Marrying a nonMuslim means abandoning Islam as well as your family. (21-year-old young women, third generation of Senegalese origin, studying accounting)

I am done with France. I don't agree with gay marriage. If I had a gay brother, you can be sure I'd stop speaking to him. (24-year-old young men, waiter, third generation of Senegalese origin)

I just cannot believe we come from monkeys. It seems horrible to me. It's not possible, we come from something much bigger, magical. In France, the only thing people believe in is science and all religions get rejected... (19-year-old young women, third generation of Moroccan, works at La Poste and studying management)

In summary, today in Les Bosquets, a new collective, self-confident, combative, and conservative expression of Islam has emerged, one with a strong sense of community cohesion built up to guard against isolation and feelings of abandonment, an Islam that provides cultural and political identification in terms of religion and traditional values, and a new collective identification whose contradictions and ambivalences are not disclosed when speaking in public (in the SI session) but are revealed in private (during biographical interviews).

\section{Taboo and the Patriarchy Model: Contradictions and Ambivalences}

The ambivalence toward religious traditions and contradictions when it comes to the system of patriarchy get reflected in individual testimonies. A young man from the third generation who defended the patriarchal system in public has to keep up appearances because he is struggling to find a job and confesses that his private life does not fit into the traditional model.

I cannot say I change diapers because this is not supposed to be my role. But I have to do it and it's hard for me [...] I would like for things to be different [...] I would like to have a job and not depend on my wife. (24-years-old, from the 
fourth generation of Malian origin; his wife is a state social worker, and they have a 6-month-old baby)

The economic crisis and the growing school dropout rate do not help young men live up to traditional models. Young women, on the other hand, with a better record of education, have become more active (Eseverri-Mayer 2019). This situation is demonstrated by a minority group ( 2 in 15 within the sample), mainly of North African background, who have developed different forms of identification. These youths have sought out contact with mixed groups in terms of ethnicity and religion, identify with groups by interest, frequent the city center, and tended to perform well in school.

We make our own lives [...] we eat in non-halal restaurants, we go to McDonald's, we go to Paris [...] I feel part of my dance group [...] I'm practicing but I have friends from all religions. I have two Jewish friends with a lot of guts... (21-year-old from fourth generation of Moroccan origin, IT student)

In fact, in Les Bosquets, only a very tiny minority have embraced strict, puritan Islam. Though they claimed to support the patriarchal system, most of them tended to shift their discourse when the interlocutor during the SI sessions was no longer an imam or a (potentially racist) Frenchman - a young female teacher of Moroccan background with a critical point of view, for example.

-"A problem we have as Muslims is the taboo of sex... something I think we young people have moved on from that, don't you think?"- says the teacher.

- "Yeah"- says 25-years-old of Malian origin-(...) here in the neighborhood, the bad thing is that hanging out with girls on the street is frowned upon, just being friends, and I think that there is a relationship problem between girls and boys and the taboo is not good...

-"Yes"- says one of the educators from the second generation- "I believe part of the violence, the frustration and anger of young people is because of that sexual repression, I say it, and no one blush now..." (laughs).

In fact, during the youth exchange in Madrid, Spanish Muslims accused their French counterparts of being ambivalent and cowardly for hiding their relationships with French boys and having pre-marital relationships. They said that this was precisely how gossip and the difference between "good girls" and "bad girls" got fueled in their neighborhood (a distinction that emerged during the journey itself). Nevertheless, after a week of being together, two of the three French girls decided to confess to the Spanish girls that they had had pre-marital relationships. A young girl had a boyfriend whom she met once a week in Les Halles (central Paris), and another girl confessed she had even had a relationship with a native French boy she felt very comfortable around. However, upon saying it, they became quite distraught and pleaded with the other French girls to not say anything on their return to Paris.

They all admit being locked into (even trapped) a set of predominately local traditions. Most accept this to avoid betraying loved ones in the face of a society that 
marginalizes or accuses them of being traitors and terrorists. Even within this context of identity reaffirmation and their sense of belonging to a global and local umma, however, young people recognize that they will always be Muslims à la français. As proof of this, only two young people in the sample group wear veils.

For me, my identity is no longer French. [...] Europeans aren't black, are they? I think we must say things the way they are (...) I am Muslim and I want to comply with the traditions, values, norms ... but then there are lots of things that distract you (...) Even if we don't want to, we will always be Muslims à la française (he laughs). (Fourth generation of Algerian origin. He just abandoned his physic studies).

\section{Poverty, Ethnic Diversity, Civic Participation, and a New Young Islam in San Cristóbal (Madrid)}

In San Cristóbal (Madrid), the findings show a different relationship between young Muslims and traditional values. In this case, Islam is refashioned and affected by civic participation. Although racism and poverty are also present, living together with different cultures and beliefs change the way young people identify with tradition and religion.

\section{The Power of "the Mix" and of Youth Engagement in a Poor Neighborhood}

San Cristóbal (14,980 inhabitants) is "the south of the south" in the city of Madrid. But unlike Les Bosquets, it has a good connection to the city center, the Puerta del Sol (20 min away by underground). The third poorest neighborhood in the city, San Cristobal, has a $31 \%$ unemployment rate (12 points higher than the city average, $18 \%$ ) and a per capita income of 16,971 Euros (compared to the 26,409 average in Madrid) (Ayuntamiento de Madrid 2016; Consejería de Educación e Investigación 2017).

Despite this precariousness, exacerbated by the economic crisis in 2008 and the world pandemic now, the type of settling by immigrants here has made ethnic concentration avoidable (Leal and Dominguez 2008). There has been no "white flight" in the neighborhood (59\% of the population is of Spanish origin) and the immigrant population is the "daughter of immigration" (Arango 2009), home to over 45 different nationalities. The Latin American population (from over 15 different countries) represents $12 \%$ of the total population, while the population from Muslim countries (Bangladesh, Pakistan, Senegal, Mali, and especially Morocco) makes up 10\%. Populations from Eastern Europe (7\%), from Asia (6\%), and other African (4\%) and European countries $(2 \%)$ are also significant.

However, the lack of institutional support has pushed the network of associations to make use of its own resources. A system of dialogue with the administrations was created in 2014 through participatory councils, which have made it possible to deal with conflicts between gangs, problems of coexistence in buildings, hunger in families 
and children, prevention of teenage pregnancies, and violence toward teachers, among other issues. These spaces of participation allow leaders of different youth, cultural, sports, religious, ethnic, and women's associations to meet every month with professionals from different social services and representatives of the city council.

Unlike in Les Bosquets, young people do not talk about isolation. They feel no need to push back at racism or the surrounding Islamophobia because the feeling of discrimination is lower, and it is accepted as a process that Spaniards must experience. Unlike in Les Bosquets, treatment from the police is not viewed as being so violent, with a distinction made between national and municipal police, and it is generally accepted with resignation. Nevertheless, even though most do not see racism as a barrier, some voices are starting to be raised in the second generations.

One day I got attacked in the restaurant where I work, some girl with a knife cut me on one hand. An ambulance came, they dressed the wound, and then the national police came. One of them asked for my ID and I gave it to him. Then he said: 'ah, so you are a Moor!' That bothered me, you know, because if I give you a Spanish ID card, it's because I'm Spanish... it's totally out of line! (21-yearsold, second generation of Moroccan origin, trying to get the Secondary Education Degree through a local Association)

Though young people do feel the discourse from the extreme right is gaining traction, for now, it is not affecting them beyond just replicating that distinction between "them" (White, Catholic, or Spanish) and "us" (Muslims). They do not experience a feeling of separation within the city in any violent way, and they all say they go into the city center at least two or three times a week. Moreover, despite the fact that peer groups in the neighborhood get formed according to national origin or ethnic group, the street, the bars, sports centers, and intermediate structures (associations, movements, and participatory councils) ensure there is inter-ethnic and inter-religious contact. It is important to note that there are 8 times the number of cafés and bars in San Cristóbal as there are in Les Bosquet (31 vs 8).

This daily contact and friction make it so they incorporate the values, cultural elements, and habits of young Latinos (such as the music, dance, street contact, and fashion) and of Spaniards (such as participation in associations, social protest actions, the kinds of leisure activities, and gender relations) and so develop a complex and mixed social belonging, a belonging that is not ideological in nature, instead multidimensional, hybrid, changing, and dynamic in character (Lamo de Espinosa 1996). These two quotations demonstrate this fluid identification.

We move like the Dominicans; we dance like they do. I get asked if I am Dominican [...] but I also have Spanish friends, and my girlfriend is Ecuadorian ... Ah, and I am Muslim! (20-year-old young man, second generation Senegalese origin. He works the night shift in a paper factory)

I feel I am Spanish, from San Cris and also Moroccan. And I feel Muslim above everything else, because I believe that borders should not exist. But we (her family) have also adopted a lot of Spanish culture. With my sisters I speak in 
Spanish, we sing Spanish songs. We don't celebrate Christmas, but we love it! The lights, the sweet bread! (Second generation of Maghreb origin, 20-year-old woman, studying social work and participates in a civic association)

The young people's local engagement in participatory councils - through the organization of parties, events, discussion groups for preventing gang violence, etc.- - facilitates inclusion and a feeling of being useful to the community. Youth from diverse ethnic and religious backgrounds start identifying with the local territory. Common interests are discovered and defended, life experience gets shared, and a new sense of belonging engendered. Sharing territory and daily contact with different ethnicities become core to their identity. The ethnic-religious elements become secondary, and Islamic traditions become offshoots that can be adapted or put together in a positive way.

Mixing with "the other" creates distance between young people and religious dogma. Though the primary group is a crucial channel for entering the job market (in construction, hospitality, and domestic service), belonging in San Cristóbal is not formed through the ethnic community. Young people frequent a variety of cultural environments, and the belonging they build is not ambivalent but rather multidimensional and dynamic.

\section{A New Free, Humanistic, and Young Islam}

The president of the local Mosque and his wife stress the need for "instructing" the residents in true Islam. Unlike in Les Bosquets, this Mosque has been on the participatory councils since their creation. Inter-religious dialogue is therefore taking place. As in Les Bosquets, the imam has a conservative approach (he has been trained in the Sunni Azhar School in Egypt), but the vast majority of the sample have a moderate or a progressive discourse about Islam.

In contrast to Les Bosquets, the session in San Cristóbal with an Islamic preacher evidenced most of the youths' dismissal of the dogmatic practices of Islam ( 9 were practicing Muslims, 4 non-practicing, and 2 atheists). The invited Islamic preacher spent the entire 3-h session defending Islam against the young people's criticisms of patriarchal systems and the discrepancies between dogma and scientific discoveries. Unlike the French youth, in San Cristóbal, the majority speak of science and knowledge as sources of progress and a guarantee for obtaining rights. A girl and boy who had read parts of the Qur'an in preparation for the session even presented a verse, which according to them, explicitly undervalued women: "It is He who created you from one soul and created from it its mate that she might dwell in security with him." Participants stressed the importance of faith over traditions. Condemnation of the social control exercised by people associated with the mosque and the local café nearby was unanimous.

This is not Islam. They are people who have nothing better to do, all they do is move back and forth between the café and the mosque. That's haram! (19-yearsold man, second generation of Senegalese origin, unemployed) 
In San Cristóbal, part of the sample belongs to the 1.75 generation (Rumbaut 2006), arrived before the age of 5, mastered the language and cultural patterns of the majority, but still have some memories of the country of origin. This makes their discourse on their expectations and relationship with the majority culture different from that of their peers in Paris. For them, their family has struggled to settle in Spain, and they are eager to enjoy the youth - "having fun in Madrid and leaving traditions for adulthood"- and also of the economic, cultural, and social opportunities the country has to offer. During the youth exchange in Madrid, a young Senegalese man said that to achieve his dream of being a chef, he spent years working as an Iberian ham cutter. He explained it was not easy to go against the commandments of Allah. Most French youths condemned his decision, while most of the Spanish defended it, claiming the most important thing in life is not dogma but rather to better yourself and succeed.

Most of the youth in the sample distinguish between Islam and ethnic norms inherited from the past, eliciting a productive confrontation between them and the traditionalism of their families or communities. They confront social norms and think identifying with religious values is not dogmatic but rather universal, humanistic, and personal.

I just ignore the people who want to impose norms. [...] I think each person should just do what feels right, especially in jurisprudence. I don't know, if it makes you feel good to wax your eyebrows and wear makeup, if your conscience is okay with something, even if for someone else it isn't, you know? We all have a male chauvinist cousin or aunt (laughs) ... But you have to listen to yourself... Then there are the basics, which are unchangeable. But people who judge [...] They are not good people. (Second generation of Maghreb origin, 20-year-old woman, studying social work)

Pre-marital relationships with the opposite sex lie at the heart of traditional taboos. Participant observation allowed us to observe that girls in Paris (Les Bosquets) hide the fact that they have this kind of relationship from not only their own community but from wider French society as well. They want to make their belonging to the Muslim community so explicit that they feel the need to prove their adherence to religious dogma to French girls too. From this comes their vindication of belonging in purely religious terms. By contrast, Muslim girls from San Cristóbal do not choose to resolve this by keeping it secret but rather take the path of conflict and confrontation. They do not hide their relationships with the opposite sex from Spanish society and even go as far as to negotiate the matter with their parents. However, their particular brand of ambivalence comes in the form of a disconnect between their claim to freely choose a partner during their youth and their adherence to traditional concepts of marriage in the future.

I'm the one who decides [...] I have a boyfriend and I also go out with my friends. My dad has given me 300 euros to go to Marbella with my sister and two friends [...] My dad always tells me I need to go to mosque, that I need to change one day... and it's true, when I get married, it'll be with someone who can 
provide for me and I'll stay at home like a queen. (Second generation of Moroccan origin, 21-years-old, waitress at night)

\section{Discussion}

The French-Algerian Imam and physics teacher began his talk to the youths by saying: "Islam defends the necessity of coexisting with others despite differences. Differences do not divide us; they bring us closer. It is the same as the principle of the communicating vessels in physics. If mixing did not exist, there would be no life." These words correspond to one of the main results of this research. Namely, the fact of socializing in a mixed environment (having friends from different backgrounds and beliefs), coming into weekly contact with the diversity of the city center, and participating in civic life leads to a dynamic (changeable) relationship with Islam and not rigid identification to traditions and norms.

In San Cristóbal (Madrid), ethnic-religious identification is not exclusive but rather one of several elements in mixed or hybrid belonging. It is a dynamic new way of taking part in a local community where social conditions and civic participation together create bonds between diverse ethnic and social groups. Young people have a role within the community, and Islam becomes a motivation for engagement, rather than an element of alienation. Identification with traditional values in San Cristóbal is not strict. Young people distinguish between spirituality and traditional dogmas, lend great importance to science, and enter into conflict with their parents for transgressing these rules.

Nevertheless, most of the participants express their desire to "settle down" in the future and becoming more religious in their adulthood. This finding raises the question: Does this spiritual and humanistic Islam correspond to a specific life moment or will it be part of a new kind of "Spanish Islam"? Young people have not developed feelings of having ruptured with the Spanish population living in the city center. This is despite a new Islamophobia being stoked by the extreme right.

These facts confirm pre-existing findings about young Muslims in Europe (Cesari 2013b; Roy 2006), who describe a young Islam as being free, individual, and private, a type of Islam that does "not influence social behavior and is disconnected from the collective identity" (Cesari 2004: 46).

That description might be accurate for most young European Muslims and in France the case for middle-class French-Muslims (Beaman 2016) and Muslims living on the outskirts besides the most segregated ones like Les Bosquets. However, the research carried out in this area shows that young people build a common belonging based on conservative Islam. They feel part of their local surroundings as well as part of something bigger (the global umma). More than ever, young people need to show their loyalty/solidarity toward their primary group, toward their family, and toward the religious community and its traditions (even if they later break from them in private and in secret). And they do so in the face of a secular tradition that, denying Islamophobia under the veil of universalism, insists on non-public expression of religious beliefs and rejects difference. This confirms findings found elsewhere in disadvantaged urban contexts (Mythen 2012). Identification with traditional values is therefore built up in 
a collective way and not individually, in the face of a shared experience of Islamophobia and feelings of isolation and abandonment by the political elite.

The Muslim community in Les Bosquets therefore has a new capacity for building internal solidarity, which turns it into a source of social capital (Portes and Sensenbrenner 1993). This collective solidarity offers young people a sense of belonging, protects them from Islamophobia, though not without negative effects in terms of gender equality and freedom of conscience. Dissent from social norms can result in isolation from family and friends and stigmatization by other community members. In this sense, the benefits of ethnic embeddedness in disadvantaged and segregated areas are being questioned in so far as they represent limitations on personal freedom, pressures to conform, and an overbearing form of control on a person's future plans and ambitions (Crul and Vermeulen 2003; Portes 1988; Waters et al. 2010; Waldinger 1995; Keaton 2006).

However, despite this new strength of the Muslim associations and the weight of traditions, this research shows a complex micro-society in Les Bosquets, one containing a minority who feel Parisian, secular, and believe in academic excellence as a means for leaving the area, another who chose puritan and rigorist Islam, and a majority who drift in ambivalence between submitting and rejecting "Frenchness," who seek to show their commitment to their origins and traditions, but who sometimes hide it and blend in with the majority of society outside the neighborhood.

In conclusion, these findings show the determinant effect of the local context (Crul and Vermeulen 2003) and the need for sociologists to get an up-close look in order to understand the complexity of each specific site. Young French Muslims in Les Bosquets seek refuge in the ethnic group because outside of it, they are not allowed to develop their citizenship. In fact, Muslimness at local level becomes the new way of acquiring collective power for getting their voices heard by the institutions. Hence, Muslim associations, with their newfound influence, also have a new responsibility toward the inclusion and education of the youth (Eseverri-Mayer 2019). In contrast, and for now, the new generation of Spanish Muslims in San Cristobal, with their desire to transgress norms, to mix with others, and interpret their own personal Islam, can express a hybrid belonging. This multicultural and multi-religious neighborhood is an example because it still manages to fight and improve social conditions by exercising an urban and local citizenship that transcends religious, ethnic, and gender divisions.

Acknowledgements I would like to thank my scientific mentor Professor Danièle Joly (Warwick University) during the fieldwork and Professor Michel Wieviorka for his institutional support at the EHESS, Paris. I also want to acknowledge the Spanish Ministry of Science (Project reference: RTI2018-095283-J-I00), the European Commission and the BBVA Foundation for allowing me to be present in these disadvantaged urban areas and be witness of young people' lives.

\section{References}

Adlbi, S. (2010). "Sometimes I am Spanish and sometimes not": A study of the identity and integration of Spanish Muslim women. Research in Comparative and International Education, 5(2), 185-204. 
Arango, J. (2009). Después del gran boom. La inmigración como bisagra de cambio. In E. Aja, J. Arango, \& J. Oliver (Eds.), La inmigración en tiempos de crisis (pp. 99-120). Barcelona: CIDOB.

Astor, A. (2014). Religious governance and the accommodation of Islam in contemporary Spain. Journal of Ethnic and Migration Studies, 40(11), 1716-1735.

Ayuntamiento de Madrid. (2016). Madrid datos. Madrid: Subdirección General de Estadística.

Beaman, J. (2016). As French as Anyone Else: Islam and the North African Second Generation in France. International Migration Review, 50, 41-69.

Bertaux, D. (1980). L’Approche Biographique : sa validité méthodologique, ses potentialités. Cahiers Internationaux de Sociologie, 69. Juillet-Décembre, 1980, 197-122.

Bouamama, S. (1993). De la galère à la citoyenneté : les jeunes, la cité, la société. Paris: Desclée de Brouwer.

Bourdieu, P. (1979). La Distinction: Critique social du jugement. Paris: Editions Minuit.

Brubaker, R. (2001). Au-delà de l'identité. Actes de la Recherche en Sciences Sociales, 139, 66-85.

Castel, R. (1995). Les métamorphoses de la société salariale. Chronique du salariat. Paris: Fayard.

Castells, M. (1997). La era de la información. Economía, Sociedad y Cultura, Vol 2. El poder de la identidad. Madrid: Alianza Editorial.

Cesari, J. (1999). Musulmans et républicains. Les jeunes, l'islam et la France. Paris: Broché.

Cesari, J. (2004). When Islam and democracy meet: Muslims in Europe and in the United States. New York: Palgrave Macmillan.

Cesari, J. (2013a). Why the West fears Islam: An exploration of Muslims within liberal democracies. New York: Palgrave Macmillan.

Cesari, J. (2013b). Self, Islam and Secular Public Spaces. In N. Gole (Ed.), Islam and public controversy in Europe (pp. 47-67). Farnham: Ashgate.

Consejería de Educación e Investigación. (2017). Informe sobre el Sistema Educativo de la Comunidad de Madrid. Curso 2013-2014. Madrid: Consejo Escolar de la Comunidad de Madrid.

Corpas, A. (2010). Las comunidades islámicas en la España actual (1960-2008). Génesis e institucionalización de una minoría de referencia. Madrid: UNED.

Crul, M., \& Vermeulen, H. (2003). The second generation in Europe. International Migration Review, 37(4), 965-986.

Donzelot, J. (2011). Le chantier de la citoyenneté urbaine. Esprit, 31, 43-67.

Dubet, F. (1987). La galère: Jeunes en survie. Paris: Fallard.

Eseverri-Mayer, C. (2015). Jóvenes en tierra de nadie. CIS.

Eseverri-Mayer, C. (2019). Linking suburban youth in Madrid and Paris. The role of civil society structures in the integration of children from Muslim backgrounds. Urban Studies, 56(13), 2616-2634. https://doi.org/ $10.1177 / 0042098018801160$.

Eseverri-Mayer, C., \& Khir Allah, G. (2020). Controling Muslim Youth Activists through unique representation Muslim Civil society in the Spanish capital. Universidad Complutense Working papers.

Fassin, D. (2006). De la question sociale à la question raciale? Représenter la société française. Paris: La Découverte.

Frost, D. (2008). Islamophobia: Examination of causal links between the state and the "race hate" from below. International Journal of Sociology and Social Policy, 28(11-12), 546-563.

Gil Araujo, S. (2010). Las argucias de la integración. Madrid: IEPALA Editorial.

Grzegorcyk, A. (2013). Social and ethnic segregation in the Paris metropolitan area at the beginning of the 21st century. Regional Studies on Development, 17(2), 20-29.

Joly, D. (2005). Hacia un nuevo paradigma musulmán en Francia y Gran Bretaña. Migraciones, 18, 11385774.

Joly, D. (2016). Women from Muslim Communities: Autonomy and Capacity of Action. Sociology, 12, 816832.

Jouili, J. (2015). Pious practice and secular constraints: women in the Islamic revival in Europe. Stanford: Stanford University Press.

Jouili and Amir-moazami. (2006). Knowledge, empowerment and religious authority among Pious Muslim Women in France and Germany. The Muslim World, 96(4), 617-642.

Keaton, T. D. (2006). Muslim girls and the other France. In Race, identity politics and social exclusion, Bloomington. Ind.: Indiana University Press.

Kepel, G. (2013). Quatre-Vingt-Treize. Paris: Gallimard.

Kepel, G. (2015). Terreur dans l'Hexagone, Genèse du djihad français. Paris: Gallimard.

Khan, S. (2016). The battle of British Islam. Reclaiming Muslim identity from extremism. London: Saqi Books. 
Khosrokhavar, F. (1996). L'universel abstrait, le politique et la construction de l'islamisme comme forme d'alterité. Wieviorka, Michel (Ed.). Une societé fragmentée. Le multiculturalisme en débat, (pg. 99-117). Paris: La Découverte.

Khosrokhavar, F. (1997). L'islam des Jeunes. Paris: Flammarion.

Killian, C. (2007). Covered girls and savage boys: Representations of Muslim youth in France. Journal of Social and Ecological Boundaries, 3(1), 69-90.

Kundnani, A. (2007). The end of tolerance. In Racism in the 21th Century in Britain. London: Pluto Press. Lagrange, H. (2010). Le déni des cultures. Paris: Éditions du Seuil.

Lamo de Espinosa, E. (1996). Sociedades de cultura, sociedades de ciencia. Oviedo: Nobel.

Leal, J., \& Dominguez, M. (2008). Transformaciones económicas y segregación social en Madrid. Ciudad y Territorio, 158, 703-725.

López, B. and Olmo, N. (1995). Islam e inmigración. En Comunidades islámicas en Europa, ed. Abumalham, M. 257-276. Madrid: Trotta.

Lopez García, B. (2009). El proceso de asentamiento y el perfil de los marroquíes en España. Diálogo Mediterráneo, n50: 45-49

Mavelli, L. (2012). Europe's encounter with Islam: The secular and the postsecular. New York: Routledge.

Modood, T. (2005). Multiculturalism politics: Racism, ethnicity, and Muslims in Britain. University of Minnesota Press.

Mogahed, D. (2007). Reinventing integration: Muslims in the West. Islam and Muslims in the World today. London: University of Cambridge.

Mythen, G. (2012). Identities in the third space? Solidity, elasticity and resilience amongst young British Pakistani Muslim. The British Journal of Sociology, 63(3), 393-411.

Naïr, Samin. (2015). El incendio de las banlieues. El País (14/11/2015).

O’Toole, T., Meer, N., \& DeHanas, N. (2015). Daniel; Jone. H Stephen and Modood Tariq. Governing through Prevention? Regulation and contested practice in state-Muslim engagement. Sociology, 50(1), $160-177$.

Observatoire National des Zones Urbaines Sensibles (ONZUS). (2014). Rapport annuel. In Observatoire National de la Politique de la Ville http://www.onzus.fr/actualites\#Rapport\%2014.

Pan Ké Shon, J. L. (2011). Residential segregation of immigrants in France: an overview. Population \& Societies, 477, 56-81.

Parekh, B. (2008). European Liberalism and "the Muslim Question". Amsterdam: Amsterdam University Press.

Portes, A. (1988). Social capital: its origins and applications in modern sociology. Annual Review of Sociology, 24, 1-24.

Portes, A., \& Sensenbrenner, J. (1993). Embeddedness and immigration: Notes on the social determinants of economic action. The American Journal of Sociology, 98(6), 1320-1350.

Portes, A., Aparicio, R., \& Wickstrom, E. (2016). Spanish Legacies. The Coming of Age of the Second Generation. California: University of California Press.

Portes, A., Aparicio, R., \& Wickstrom, E. (2017). General trends and exceptions in the incorporation of immigrant youths to host societies. Ethnic and Racial Studies, 41(3), 517-521.

Portes, A., Aparicio, R., \& Wickstrom, E. (2018). Investigación Longitudinal de la Segunda Generación (ILSEG en España). Informe preliminar): Tercera Fase 2016.

Prada, M. Á. (2000). La inmigración extranjera en la Comunidad de Madrid. Consolidación del hecho migratorio y emergencia de un modelo de gestión de la diversidad. Estudios del Colectivo IOE, 1-27.

Preteceille, E. (2011). Has ethno-racial segregation increased in the Greater Paris Metropolitan Area? Revue française de sociologie, 52(5), 31-62.

Ramadan, T. (2002). El Islam minoritario: cómo ser musulmán en la Europa laica.

Ramadan, T. (2003). Les musulmans d'occident et l'avenir de l'islam. Paris: Sindbad.

Ramadan, T. (2004). Western Muslims and the future of Islam. New York: Oxford University Press.

Ramirez, A., \& Mijares, L. (2009). La "islamización” de la inmigración. Cuadernos del Mediterráneo, $n^{\circ}$ 9, 389-392.

Roy, O. (2005). La laïcité face à l'islam. Paris: Stock.

Roy, O. (2006). L’Islam de France. Confluences Méditerranée., 2, 49-55.

Roy, O. (2009). Secularism confronts Islam. New York: Columbia University Press.

Rumbaut, R. G. (2006). Edades, etapas de la vida, y cohortes generacionales: Un análisis de las dos primeras generaciones de inmigrantes en Estados Unidos, In, Alejandro Portes y Josh DeWind (Ed.), Repensando las migraciones: Nuevas perspectivas teoricas y empiricas. Mexico: Instituto Nacional de Migración.

Téllez Delgado, V. (2011). Contra el estigma: jóvenes españoles/as y marroquies transitando entre la ciudadanía y la "musulmaneidad". Doctoral thesis from the Universidad Autónoma de Madrid. 
Touraine, A. (1965). Sociologie de l'action. Paris: Seuil.

Touraine, A. (1978). La voix et le regard. Paris: Seuil.

Touraine, A. (1991). Face à l'exclusion. Esprit, Février, 7-13.

Tribalat, M. (2010). Les Yeux grand fermés. L'immigration en France. Paris: Denoël.

Veredas, S. (2011). Identidad étnica y género entre adolescentes de origen marroquí. Papers, 96(1), 117-144.

Wacquant, L. (2002). Parias urbanos: marginalidad en la ciudad. Buenos Aires: Manantial.

Wacquant, L. (2008). Urban outcasts. A comparative sociology of advanced marginality. Cambridge: Polity Press.

Waldinger, R. (1995). The other side of embeddedness: A case study of the interplay of economy and ethnicity. Ethnic and Racial Studies., 18, 555-580.

Waters, M. C., Tran, V. C., Kasinitz, P., \& Mollenkopf, J. H. (2010). Segmented assimilation revisited: Types of acculturation and socioeconomic mobility in young adulthood. Ethnic and Racial Studies, 33, 11681193.

Wieviorka, M. (1999). Violence en France. Paris: Seuil.

Wihtol de Wenden, C., \& Leveau, R. (2001). La beurgeoisie. Les trois âges de la vie associative issue de l'immigration. CRNS Editions: Paris.

Zapata, R. (2006). Multiculturalism, Muslims and citizenship: A European approach. In T. Modood, A. Triandafyllidou, \& R. Zapata-Barrero (Eds.), Multiculturalism, Muslims and citizenship: A European approach (pp. 143-161). Routledge: London.

Publisher's Note Springer Nature remains neutral with regard to jurisdictional claims in published maps and institutional affiliations. 